\title{
The role of disease resistance in the registration of crop varieties in Hungary
}

\author{
László Gergely - Bernát Poós \\ National Food Chain Safety Office, Budapest, Hungary \\ gergelyl@nebih.gov.hu
}

\begin{abstract}
SUMMARY
Variety testing including disease resistance test of the major crops has been carrying out since the 1960's in Hungary. Testing for resistance of the new candidate varieties is performed in the so-called VCU (Value for Cultivation and Use) trials under natural infection and in special small-plot or micro-plot trials using different disease provocative methods. Disease resistance, especially those of multiple and horizontal-type (race non-specific, partial or durable) resistances, has recently become a key limiting factor in the state variety registration. The role of disease resistance in the decision-making process of variety registration is demonstrated on the examples of winter wheat and sunflower as two major field crops in Hungary.
\end{abstract}

Keywords: variety testing, VCU and provocative trial, testing for resistance, multiple disease resistance, sustainable agriculture

\section{INTRODUCTION}

Variety testings including disease resistance test of the field crops has been carrying out since the 1960's in Hungary. Nowadays there are seventeen Variety Testing Stations belong to the National Food Chain Safety Office where the field performance (VCU) trials and the small-plot disease provocative trials are conducted. There are two additional resistance tests under glasshouse conditions and one test under walk-in plastic tunnel assessing the resistance of sunflower candidates to downy mildew (Plasmopara halstedii) and broomrape (Orobanche cumana), and the foliar resistance of new potato varieties to late blight (Phytophthora infestans), respectively (Gergely, 2007). In the last several decades there has been a change in the paradigm of breeding for resistance. Due to the vulnerability of vertical (race-specific) resistance resulted in new races that overcome the dominant genes for resistance in host plants, horizontal-type resistance (also called race-non-specific or partial resistance) has become a priority in the resistance breeding programmes providing a desirable durable resistance against plant diseases.

\section{MATERIALS AND METHODS}

The methodology used in resistance testing has been developed since the 1960's and is being developed continuously (Hinfner and Homonnay, 1966; Hinfner and Békési, 1971; Gergely, 2004). According to these studies the two principal components of resistance testing are the correct diagnosis and the precise determination of the infection rate. In general, three evaluation methods are used to determine the actual rate of infection. Firstly, percentage of infected plants (infected plant \%) in case of systemic diseases caused by viruses, and wilts caused by fungi or bacteria. Secondly, estimating the rate of infection using a 1-5 or 1-10 grade scale of increasing susceptibility (infected leaf/stem area \%) in case of powdery mildews, rusts, leaf and stem spot diseases, respectively. And thirdly, calculating an index of infection which is a combination of the last two methods expressing not only the incidence but the severity of the disease (index of infection \%).

Candidate varieties tested are classified into five resistance categories according to their disease severity. Classification is practically based on the deviation between the infection rate of each genotype and the actual trial mean which is considered to be $100 \%$. If the trial mean is less than $50 \%$, a given candidate variety is

$\mathbf{1}=$ resistant, if its rate of infection does not exceed $25 \%$ of the trial mean,

$\mathbf{2}=$ moderately resistant, if its rate of infection is $26-75 \%$ of the trial mean,

$\mathbf{3}=$ mid-susceptible, if its rate of infection is $76-125 \%$ of the trial mean,

$\mathbf{4}=$ susceptible, if its rate of infection is $126-175 \%$ of the trial mean, and

$\mathbf{5}$ = highly susceptible, if its rate of infection exceeds $175 \%$ of the trial mean

In the cases when the trial mean exceeds $50 \%$ (severe disease outbreaks, provocative trials) the percentage values of the actual disease severity correspond to the following ratings of resistance/susceptibility:

$1=$ resistant, if the disease severity is $0-20 \%$,

2 = moderately resistant, if the disease severity is $21-40 \%$,

3 = mid-susceptible, if the disease severity is $41-60 \%$,

4 = susceptible, if the disease severity is $61-80 \%$, and

$\mathbf{5}=$ highly susceptible, if the disease severity is $81-100 \%$

(after Hinfner and Homonnay, 1966) 
Testing for resistance of the new candidate varieties is performed in VCU trials under natural infection and in special small-plot or micro-plot trials using different disease-provocative methods. Four provocative methods and their combinations are used in practice:

- Micro-climate provoked one, when the geographical position of the trial site is favourable for disease development (e.g. high yearly precipitation and relative air humidity favour the incidence of fungal and bacterial diseases)

- Monoculture which is known to increase disease incidence through contamination of soil in the experimental site with resting spore of pathogens such as oospores, chlamidospores, sclerotia, etc.

- Use of provocative plots when every second plot in a field trial block is sown with susceptible varieties (e.g. wind-borne diseases such as powdery mildews and rusts). Its main advantages are earlier disease incidence and uniform infection pressure in the trial.

- Inoculation (artificial infection techniques) when the inoculum (mainly as a watery suspension of conidia or sporangia) is sprayed onto the foliage of candidate varieties in their susceptible growing stage)

In the field VCU and provocative trials the resistance/susceptibility is assessed when the infection pressure is high enough to determine the differences in the susceptibility of candidate varieties (practically when the trial mean is or exceeds $10 \%$ ). Beside the agronomic standard varieties carrying high productivity and quality, resistant and susceptible standard cultivars are also used comparing the behaviour of candidate varieties to them.

\section{The requirements of variety registration}

- $\quad$ Fulfilment of the so-called DUS (D=Distinctness, $\mathbf{U}=\mathbf{U}$ Uniformity, $\mathbf{S}=$ Stability) requirements for breeder's right protection. The candidate variety must be differentiated from any other known cultivar, and must be sufficiently uniform and stable.

- Successful VCU performance in the small-plot performance trials with 4 repetitions in 6-8 trial sites for 2-3 years using high-yielding and high-quality standard varieties to compare.

- Main components of Value for Cultivation and Use are productivity, quality, disease resistance and agronomical features such as earliness, resistance to lodging, drought tolerance, winter hardiness, etc.

- $\quad$ Proper (acceptable) variety denomination

\section{RESULTS}

\section{Evaluation of disease resistance in the Variety Registration Process of Hungary}

\section{Demonstrated on example of winter wheat}

Major diseases in Hungary that are considered to be compulsory-tested in VCU and/or provocative trials:

1. Powdery mildew (Blumeria graminis f. sp. tritici)

2. Black (stem) rust (Puccinia graminis f. sp. tritici)

3. Brown (leaf) rust (Puccinia recondita)

4. Yellow (stripe) rust (Puccinia striiformis var. striiformis)

5. Fusarium head blight (Fusarium graminearum, F. culmorum)

6. Tan leaf spot (Pyrenophora tritici-repentis, anamorph: Drechslera tritici-repentis)

If a given candidate variety is proved to be susceptible (resistance rank 4) to at least two or highly susceptible (resistance rank 5) to at least one of the above-mentioned major diseases, the trial officer's proposal to the National Variety Registration Committee must be refusal. In other words, candidate varieties carrying more than mid-level susceptibility to the economical important diseases can be excluded from state variety registration in Hungary (Poós, 2015).

\section{Demonstrated on example of sunflower}

Major diseases in Hungary that are considered to be compulsory-tested in VCU and/or provocation trials:

1. Having downy mildew (Plasmopara halstedii) resistance to the prevalent five races/pathotypes of the oomycete pathogen $(100,700,710,730,330)$ is obligatory.

2. Sclerotinia stem and head rot (Sclerotinia sclerotiorum)

3. Diaporthe stem spot and rot (Diaporthe helianthi, anamorph: Phomopsis helianthi) 
A given candidate variety cannot be susceptible (rank 4) to the last two major diseases or highly susceptible (rank 5) to one of them. In other words, candidate varieties carrying susceptibility to the prevalent races of sunflower downy mildew in Hungary or indicate susceptibility to the two other major diseases or prove to be highly susceptible to one of them can be excluded from the state variety registration.

\section{DISCUSSION}

Genetic uniformity of the variety structure of any field crop can cause severe disease outbreaks and subsequent considerable yield losses. Black (stem) rust on winter wheat caused an epidemic in 1972 in Hungary and a newly registered Hungarian wheat variety of that time, Kiszombor 1 proved to be highly susceptible and as a consequence it was cancelled (withdrawn) from the National List of Varieties. A sunflower disease called Diaporthe stem rot (Diaporthe helianthi) also caused an unexpected outbreak in 1997 when most of the cultivars proved susceptible resulting in practically half of the nationwide average yield (1.1 tons ha-1). The potato late blight pathogen, a fungus-like oomycete organism, Phytophthora infestans caused the Great Famine in Ireland in 1845-46 when a high-yielding but highly susceptible potato cultivar, Lumper was almost exclusively grown. An infamous pathotype (race T) of the fungus pathogen, Helminthosporium maydis (since reclassified as Bipolaris maydis) swept over the southern part of the USA in 1970. At that time about $80 \%$ of the hybrid maize in America contained T-cytoplasm which is determined the susceptibility to this disease (Southern Corn Leaf Blight). Consequently, the genetic uniformity in the America's maize crop was the principal cause of the 1970 epidemic.

\section{The benefits of host resistance are the follows:}

- This is the only effective control in some cases (e.g. virus diseases such as PVY in potatoes, BNYVV in sugar beet, ashy stem blight in sunflower and Fusarium wilt in peas),

- A cheap and easy-to-use way of plant protection (choosing resistant cultivar),

- It is practically not influenced by weather conditions

- The best strategy for avoiding disease epidemics (host resistance with diverse genetic background),

- Means the best solution to reduce pesticide pollution of the environment and derease human health risks.

\section{CONCLUSIONS}

Some changes in the paradigm of variety registration have been experienced in the last decades in Hungary since resistance (preferably multiple resistance) to the major diseases of field crops has become one of the top priorities. Usage of registered varieties carrying multiple disease resistance could be the best strategy for the sustainable crop production systems such as integrated and organic farming. Nationwide testing of new crop varieties in VCU and disease provocative trials are essential due to the great differences in climate conditions and population structure of pathogens among the EU member states.

\section{REFERENCES}

Hinfner, K. and Homonnay, F. (1966): A répa betegségei és kártevői. (Diseases and pests of sugar beet) Mezőgazdasági Kiadó, Budapest, pp. 151-158.

Hinfner K. and Békési P. (1971): Rezisztenciavizsgálatok elvi alapjai és a fertőzöttség mérésének módszerei. (Theoretical implications of testing for resistance and methods for measuring the infectiveness). 1971.évi Országos Fajtakísérletek (Az Országos Mezőgazdasági Fajtakísérleti Intézet kiadványa) (Publication of the National Institute for Agricultural Variety Testing), pp. 113-126.

Gergely L. (2004): Burgonyafajták rezisztenciavizsgálata fitoftóra- (Phytophthora infestans) fertőzéssel szemben és egyes környezeti tényezők hatása a betegség-ellenállóságra. (Testing for resistance of potato varieties to late blight agent (Phytophthora infestans) and the effect of certain environmental factors on disease resistance), Doktori (PhD) értekezés (Thesis), Keszthely, 94 pp.

Gergely L. (2007): Burgonya és napraforgó fajtakísérleti módszertan (Variety testing methodology of potato and sunflower), A Nemzeti Élelmiszerlánc-biztonsági Hivatal honlap-információja (Website information of the National Food Chain Safety Office, www.nebih.hu)

Poós B. (2015): Búza fajtakísérleti módszertan. (Variety testing methodology of wheat), A Nemzeti Élelmiszerlánc-biztonsági Hivatal honlap-információja (Website information of the National Food Chain Safety Office, www.nebih.hu) 